\author{
Anna Grzegorczyk \\ University of Warsaw \\ Faculty of Geography and Regional Studies \\ Institute of Regional and Global Studies \\ e-mail: anna.torbicz@uw.edu.pl
}

\title{
SETTLEMENT AND TRANSPORT NETWORK DIVERSIFICATION AND COMPLEXITY IN HONDURAS
}

\begin{abstract}
The aim of the article is to examine the level of diversity and complexity of the Honduras settlement and transport networks and to identify processes responsible for the development of such networks. According to the analysis, the networks disproportion is not high in Honduras but it can increase in the future due to the attraction of the core areas, emergence of growth poles, migrations and concentration of international trade. The settlement and transport networks are hierarchised.
\end{abstract}

Key words: settlement network, transport network, Honduras, Landsat ETM+ images interpretation, chorèmes spatial model, Zipf's rule.

\section{INTRODUCTION}

In the 1960s, two theories were proposed which to the greatest extent refer to the spatial and structural development of settlement and transport networks in the developing countries. These are: J. Friedmann's core-periphery model (Rościszewski, 1974, Grzeszczak, 1981; Potter, 1999) and the theory of transport development in the developing countries formulated by J. Taaffe, R. L. Morrill and P. Gould (1963). These theories broadly determined the aim of the article, which was to examine the level of diversity and complexity of the Honduran settlement and transport networks and to identify the processes responsible for the development of such networks.

\section{METHODS OF RESEARCH}

In the first stage of the analysis, the satellite images and road maps were visually interpreted to produce data concerning built-up areas and transport 
(primary roads and railways length). At the next stage, the chorèmes spatial model was created, using R. Brunet's methodology (1986), to show processes shaping the settlement and transport network. Bold description in the text is at the same time the description of symbols (chorèmes) in the model's key (Fig. 1). Furthermore, the data obtained from the interpretation of images were referred to base fields with the size of $10000 \mathrm{~km}^{2}$ and $2500 \mathrm{~km}^{2}$, and then the share of built-up areas and primary roads and railway lines densities were calculated. Additionally, choropleth maps were elaborated to facilitate the interpretation of the results. Networks diversity was analysed using the coefficient of variation for the share of the built-up areas, primary roads and railways densities. The complexity of networks was examined using extensive methods. The first one, Zipf's rule, was intended to show the complexity of the structural settlement network. The method was modified and the built-up areas were arranged according to their surface areas obtained from satellite images. The traditional Zipf method was also used (Zipf, 1949). As the population data were available for 39 cities only (City Population, 2008), the method for built-up areas was used for only 50 settlements even though much more information was available. However, both methods needed to be comparable. The nearest neighbour index defined the level of the spatial complexity of the settlement network (concentration-dispersion), whereas the complexity of the transport network was identified using groupings of the transport characteristic features.

\section{AREA OF RESEARCH}

The problem was verified using a case study of Honduras. The country is relatively small (112 $090 \mathrm{~km}^{2}$ and 6320000 inhabitants in 2001) and is the second poorest country in Central America, with an unequal distribution of income and the economy relying on a few export products, mainly bananas and coffee (Earthtrends Environmental Portal, 2008). In 2001, the HDI was 0.667 and GDP in PPP per capita was USD 2830 (Human Development Report $2003,2003) .2001$ is the base year for the analysis due to the highest satellite images availability.

\section{SPATIAL ORGANISATION STRUCTURE}

Landscape is the main element of Honduras' natural conditions that influence its spatial organisation structure. In the north and south, there is a narrow lowland strip with swampy Costa de Mosquitos. The interior is mountainous with spacious highlands that altogether cover $80 \%$ of the countries area.

In the past, the isolated valleys in central Honduras were settled. The foundation for the current settlement system was created in the 
pre-colonial and colonial period. Until now, the central part of the country remains the most developed. All of the colonial towns were established across the country, and therefore spacious areas were uninhabited. The settlements on the northern coast started to emerge at the end of the $19^{\text {th }}$ century.

Most of the mines are currently closed. However, El Mochito, the greatest mine in Central America situated in the west of the country, is still open. Zinc, lead and silver ores are mined there.

Other very important elements of the spatial structure are banana plantations, founded at the end of $19^{\text {th }}$ century, along the northern lowlands. They are owned by United Branch and Standard Fruit, two American transnational corporations (TNCs). In 1993, the plantations covered $245 \mathrm{~km}^{2}$ and were 1,5 times bigger than in 1974 (Kok, 2004). The other cash crops and the main export products cultivated on the plantations include coffee and sugar cane.

At the end of $19^{\text {th }}$ century, the TNCs mentioned above built two separate railway lines in the north of the country. They link the plantations with seaports, although they do not reach the capital city and, due to having different gauges, they do not act as integration corridors. However, they are important transport corridors as most of Honduran international trade flows through them. Their total length accounts for $700 \mathrm{~km}$ (CIA, 2009). The main development axis runs along the Choluteca-Tegucigalpa-San Pedro Sula-Puerto Cortés route, which is the Pan-American highway branch. Its main axis runs from Salvador through Nacaome and Choluteca to Nicaragua on the Honduras territory. There are branches to the neighbouring countries from the development axis. The roads' length is $13600 \mathrm{~km}$ (CIA, 2009).

\section{SPATIAL ORGANISATION DYNAMICS}

The spatial dynamics is principally characterised by attraction of two core areas, which are multifunctional and international significance centres. $73 \%$ of the urban population and $25 \%$ of the total country population (Merrill, 1995) live in Tegucigalpa, the administrative capital city, and San Pedro Sula, the economic capital city. Tegucigalpa is the biggest Honduran city, with 766000 inhabitants and the built-up area of $75 \mathrm{~km}^{2}$ in 2001 (City Population, 2009; author's calculation). It was developed mainly in the $1970 \mathrm{~s}$ and $1980 \mathrm{~s}$ due to rural-urban migrations, when the cities' population rose by $75 \%$ and 80\%, respectively (Merrill, 1995). The city still expands spontaneously, becoming a chaotic metropolis with most of its population living in low-standard dwellings. San Pedro Sula, the second largest city in Honduras, is developing as the country's industrial centre. Between 1950 and 1980, its population increased much faster than that of Tegucigalpa, due to rural-urban migrations. In 2001, it was inhabited by 438000 people and the built-up area covered $40 \mathrm{~km}^{2}$. 
La Ceiba is an important growth pole $\left(11 \mathrm{~km}^{2}\right.$ and 114000 inhabitants in 2001) and its functions are associated with fruit plantations as well as the tourist sector. The other growth poles are: Puerto Cortés - the greatest Honduran seaport (products are exported to the USA after customs clearance) with an oil refinery and well-developed food industry; Puerto Castilla - the second greatest port on the northern coast; Choluteca - transport (the biggest city on the Pan-American Highway in Honduras) and trade centre. The group of growth poles also consists of industrial parks and duty free zones e.g.: Puerto Cortés, Omoa, Coloma, Tela, La Ceiba and Amapala. Hence, this Caribbean region is dubbed a "newly developing industrial strip" (Merrill, 1995). Core areas as well as growth poles having the largest spheres of influence and the greatest development potential form the first-ranked circles of the growth zones in Honduras.

The regional centres have lesser significance and are inhabited by around several thousand people and cover below $10 \mathrm{~km}^{2}$. This group of towns additionally consists of 18 department capitals (first-order administrative units). Around the regional centres, there are the second-ranked circles of growth zones.

Inner migrations have been on the increase since the beginning of the $20^{\text {th }}$ century and are associated with job opportunities on the plantations and in the trade sector in the north of the country. Rural-urban migrations were particularly dynamic in the second half of the $20^{\text {th }}$ century, from southern and western Honduras to the northern cities and Tegucigalpa. These directions are supposed to intensify in the $21^{\text {st }}$ century, and are expected to lead to greater spatial dynamics in Honduras.

Immigration from the neighbouring countries is a dominating direction among external migrations. These are mainly economic migrants looking for job opportunities on the plantations. Refugees from Nicaragua, Guatemala and Salvador are another group of migrants.

In the $1980 \mathrm{~s}$, there were around 60000 refugees and after the conflict in Salvador in the first half of the 1990s - 250000 (Merrill, 1995). They concentrate mainly in the vicinity of the border.

Political and economic contacts were inhibited by conflicts and an unstable political situation in the region. Because of the border disputes between Honduras and Salvador, there were 300000 Salvadorean immigrants in Honduras in 1968. The Football War of 1969 resulted in the escape of around 60 000-130 000 Salvadoreans from Honduras, border closure and trade disruption between the countries (Merrill, 1995). In the east, another conflict concerned the Contras guerrilla formation in Honduras and their fight against the Marxist government in Nicaragua in the 1980s. These were the reasons for inner destabilisation in eastern Honduras.

Trade exchange directions are not diversified. The USA is the main trade partner (67\% of exports and 52\% of imports), and Puerto Cortés, Puerto Castilla, Tela and La Ceiba ports are the chief gateways. The second-ranked trade partners are situated on the west - these are Guatemala (4\% of exports 


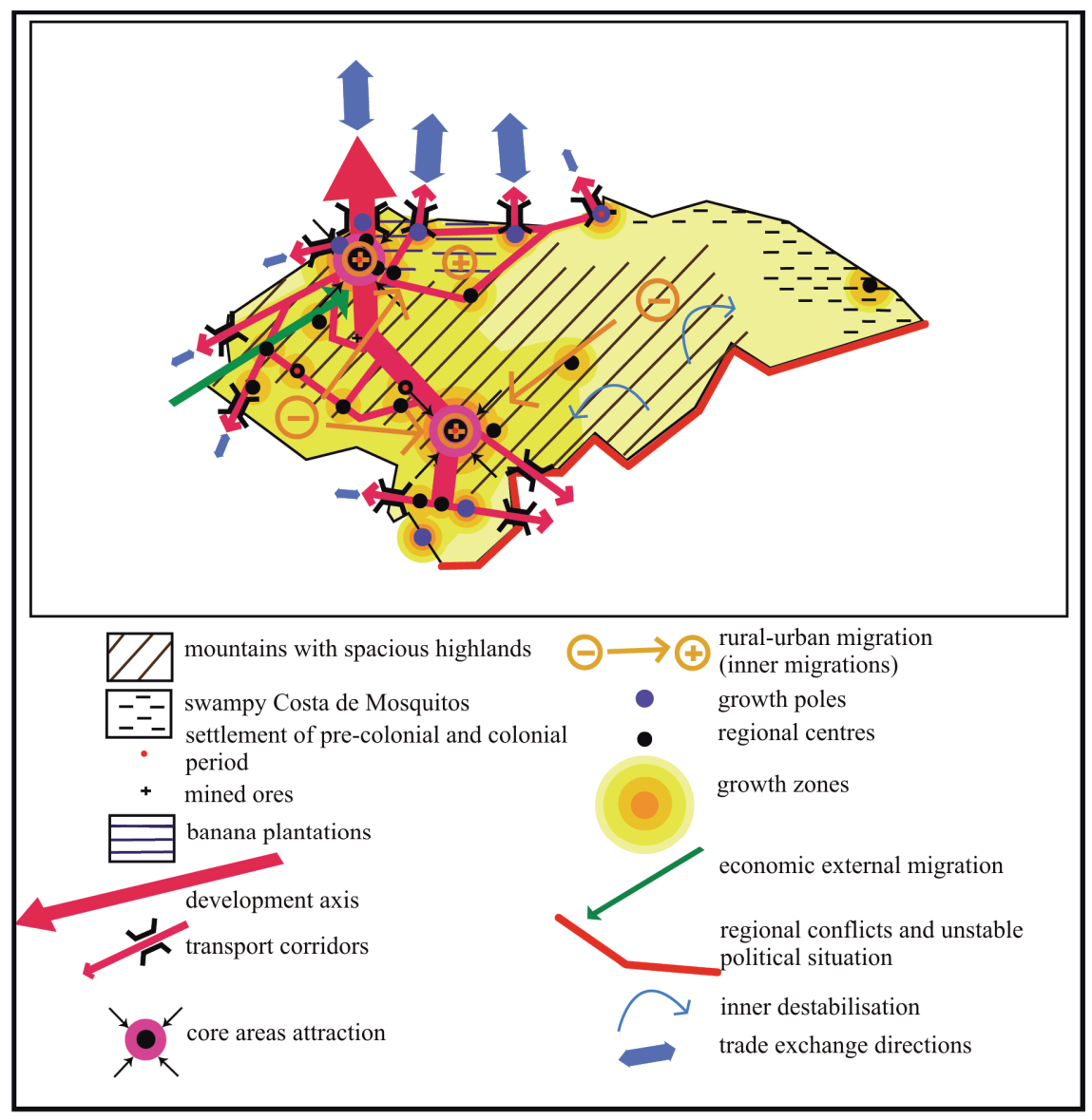

Fig. 1. Honduras Spatial Model

and 7\% of imports) and Salvador (5\% of exports and imports) (CIA, 2009). Additionally, these countries are the richest in the region and between them and Honduras there has been no conflict in recent history. The trade exchange with the poorest Nicaragua is the lowest in volume. However, the trade linkages with all the region's countries have tightened since the 1960s, when Central American Common Market was founded.

\section{NETWORK CHARACTERISTICS}

An analysis of the coefficients of variation reveals minor inequalities in the settlement and primary roads networks, which account for 2.0 and 1.1, respectively. The built-up areas and primary roads are concentrated in the centre and in the north of the country (Figs. 2, 3). However, their densities 
are not high and the peak values are ca. $20 \mathrm{~km}^{2}$ and $55 \mathrm{~km}$ for $10000 \mathrm{~km}^{2}$, respectively. There is one exception from the aforementioned pattern - the railways density is considerably diversified and concentrated entirely in the north, where it reaches the peak values $-54 \mathrm{~km}$ per $10000 \mathrm{~km}^{2}$ (Fig. 4). The eastern peripheries are the least developed (Figs. 2, 3, 4).

An analysis of Zipf's rule in relation to the settlements in terms of the population and surface area indicates that the settlement network development is close to an equilibrium (Figs. 5, 6). Tegucigalpa, a first-rank city, reveals a poor settlement network development - the city is neither big nor has a large population. Tegucigalpa is almost two times bigger than San Pedro Sula in terms of the population and surface area. The second-ranked city is 3,4 times bigger than the third-ranked in terms of the surface area (3,8 in terms of the population), showing a tendency for a binary settlement pattern. The other towns decrease gradually - the curve bands slightly and is close to Zipf's rule line (Figs. 5, 6). In Figure 6, the curve slumps, which means that the rule does not describe the pattern of settlements smaller than 6000 people. The mean contrast coefficient $\bar{a}$ is close to 1 (1,12 in terms of the built-up areas and 1,29 in terms of the population) and therefore confirms the pattern described. To conclude, we can say that in Honduras unification and diversification forces are similar, which means that the settlement network is equally developed throughout the country.

The nearest neighbour index of 0,55 reveals a slight settlement tendency for concentration. Such a value is obtained due to an equal distribution of settlements across the country, mainly in the centre and in the west. In the northern part of Honduras, built-up areas cluster, and create the industrial strip described above. However, this area is not sufficiently developed to decrease the index. Although the eastern part is not developed, it does not involve a significant area of the country.

The Honduran transport network mainly consists of roads. There are 6 branches from the main transport corridor to the regional centres (Juticalpa, La Esperanza, Santa Bárbara, Trujillo) and cities in the neighbouring countries (Ciudad de Guatemala, San Salvador). The eastern linkages are poorly developed - there is only one connection with Nicaragua via the Pan-American Highway. The railway has only local importance in spite of the fact that a FERISTA project was put forward in order to integrate Central American railways with the United States and Canadian railways in the north and Andean in the south (Honduras This Week, 2009).

The chorèmes method revealed that spatial dynamics significantly shifts from the Honduras centre northwards, where growth is concentrated, as well as foreign trade gateways and international and domestic migrations. The core area of Tegucigalpa also develops rapidly but does not produce such an extensive development area. The central and northern regions are connected via the development axis, which, together with other transport corridors, covers almost the whole of the country's area. The stagnation of the eastern regions is caused mainly by environmental, historical and geopolitical conditions. 


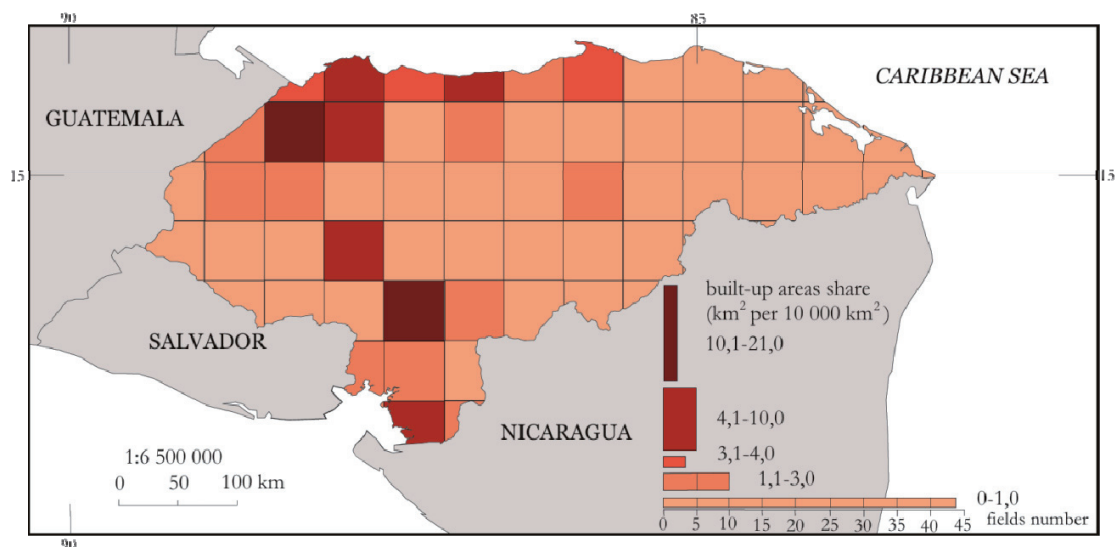

Fig. 2. Built-up areas share per $10000 \mathrm{~km}^{2}$ in Honduras

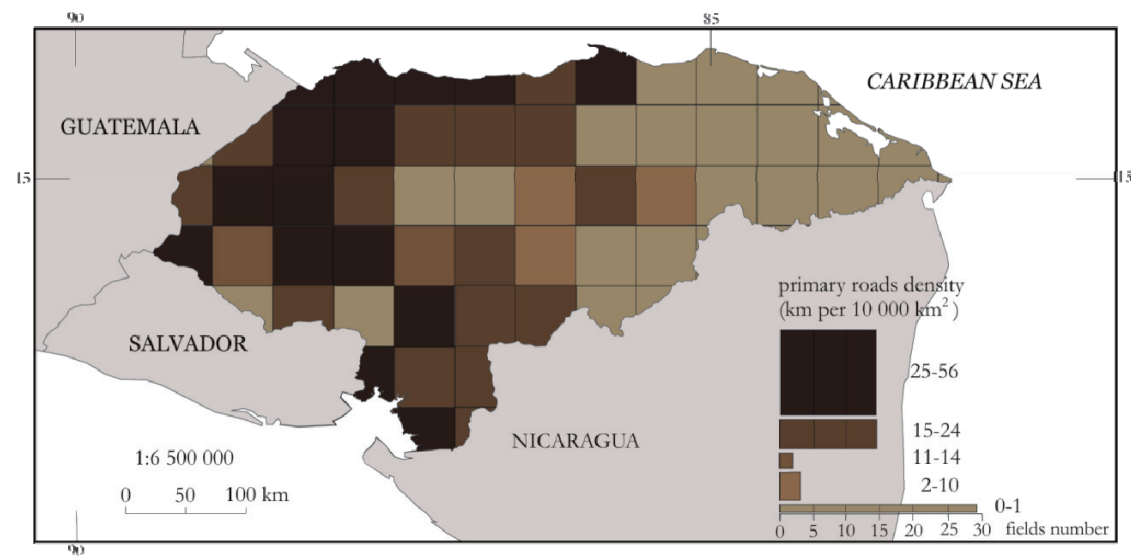

Fig. 3. Primary roads density per $10000 \mathrm{~km}^{2}$ in Honduras

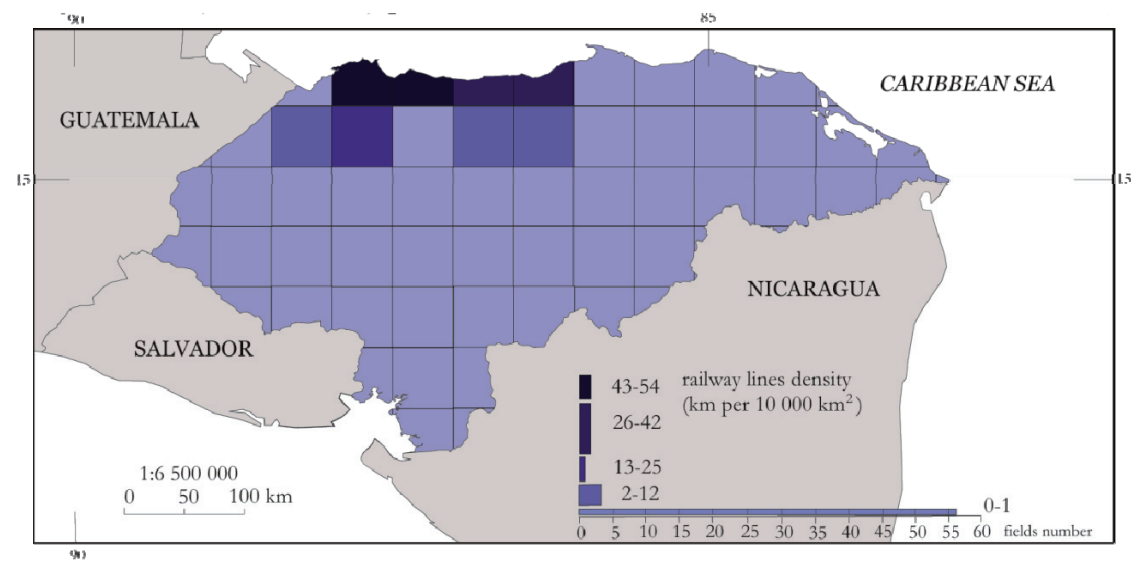

Fig. 4. Railway lines density per $10000 \mathrm{~km}^{2}$ in Honduras 


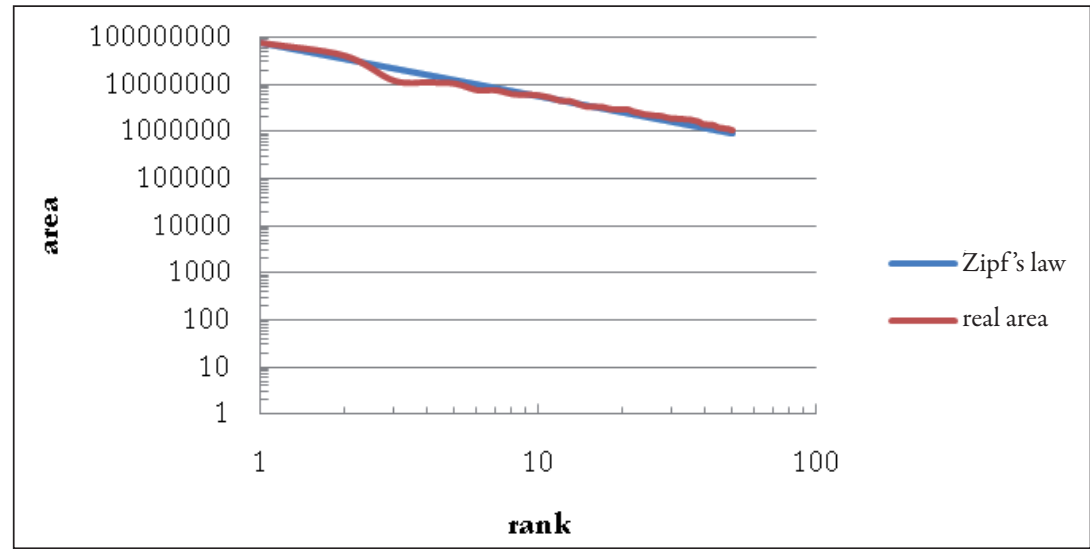

Fig. 5. Zipf Rule for Built-up Areas in Honduras

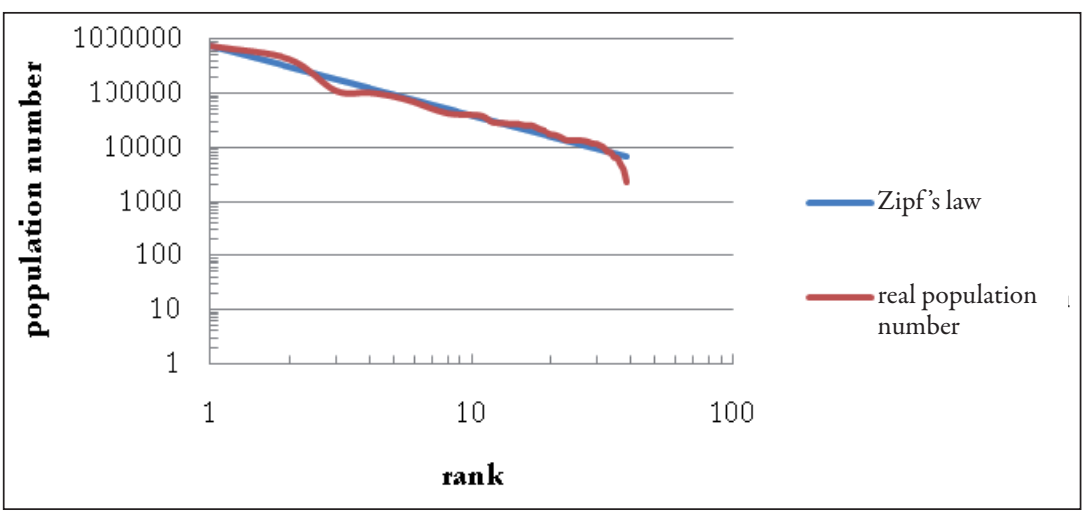

Fig. 6. Zipf Rule in Honduras

\section{CONCLUSIONS}

The analysis indicates that the settlement and transport networks of Honduras are mildly developed. With the exception of the eastern part, the diversity of networks' development is not high. Two major cities basically dominate the settlement system. The system also consists of dispersed regional centres distributed across the country as well as compact urbanised areas in the north. The transport network is directed outwards to the north and west of the country, where it is the most developed.

The networks patterns described in the article were mainly shaped by convergence forces, which operate in different parts of the country. The capital city status and migrations associated with it are balanced by the socio-economic attraction of cities in the north of the country and concentration of economic activity along the coasts, coupled with economic foreign and 
domestic immigration. The two-level administrative division makes the networks' convergence stronger.

The predominance of convergence forces inhibits the diffusion of the settlement and transport networks to the peripheries and suggests a greater spatial inequality in the future. Even though Honduras has entered the third stage of J. Friedmann's model, the absorption of peripheries does not occur, as was assumed in the theory. Hence, the study revealed that the J. Friedmann's theory was too optimistic in the case of Honduras. The E.J. Taaffe, R.L. Morrill and P. Gould model describes the transport development in Honduras rather well. The continued importance of the seaports and the main transport corridor joining them with the capital city was confirmed. The transport network is directed outwards and serves the needs of international trade, the most important source of Honduran revenues. Both networks under analysis are hierarchised but only in the most intensely developed areas.

\section{REFERENCES}

Brunet R., 1986, La carte-modèle et les chorèmes, Mappemonde, Maison de la Géographie, Montpellier, no. 4, pp. 2-6.

Central America 1:1100000, 2008, ITMB Publishing Ltd., Canada.

CIA. The World Factbook, www.cia.gov.pl, January 2009.

City Population, www.citypopulation.de, September 2008.

Earthtrends Environmental Portal, www.earthtrends.wri.org, January 2008.

Global Land Cover Facility, University of Maryland, glcf.umiacs.umd.edu/data/landsat/, December 2006.

Grzeszczak, 1981, Problemy geografii rozwoju [Development geography issues], PZLG, no. 4.

Human Development Report 2003, 2003, UNDP, New York.

Kok K., 2004, The Role of Population in Understanding Honduran Land Use Patterns, Journal of Environmental Management, vol. 72, pp. 73-89, www.elsevier.com, October 2009.

Merril T. L. (ed.), 1995, Honduras. A Country Study, Area Handbook Series, Library of Congress, Federal Research Division Defense Department, Army, lcweb2.loc.gov/frd/cs/ hntoc.html, January 2009.

Potter R. B. et al., 1999, Geographies of Development, Longman, London.

Rościszewski M., 1974, Przestrzeń krajów Trzeciego Świata. Problemy metodologiczne [Space in Third World countries. Methodological problems], PZLG, Warszawa.

Taaffe J., R.L. Morrill, P. Gould, 1963, Transport Expansion in Underdeveloped Countries: a Comparative Analysis, Geographical Review, vol. 53, no. 4, pp. 503-529.

Zipf G.K., 1949, Human Behaviour and the Principle of Least Effort. An Introduction to Human Ecology, Addison-Wesley Press Inc., Cambridge, Massachusetts. 